\title{
Making Sense of Contaminants: A Case Study of Arviat, Nunavut
}

\author{
MARTINA TYRRELL ${ }^{1}$
}

\author{
(Received 31 October 2005; accepted in revised form 11 April 2006)
}

\begin{abstract}
Inuit and scientists are increasingly aware of the presence of contaminants in the Arctic food web and of the threat these contaminants pose to human and environmental health and well-being. The varied ways that Inuit think about and react to contaminants in the foods they eat are explored in a case study of one Inuit community: Arviat, on the northwest coast of Hudson Bay. Reactions to contaminants are mixed. While Inuit are informed of scientific findings through a variety of media, they also have their own explanations for the changes that are taking place in the animals on which they rely. This study juxtaposes global cause and effect, as understood by the scientific community, and the local causes and effects of contamination as understood by Inuit. The Inuit of Arviat are incorporating contaminants research into their hunting practice and earning money by collecting tissue samples and hosting southern researchers. This typical Nunavut community demonstrates the heterogeneity of understanding that exists and the ways in which local people are turning something very negative to their advantage.
\end{abstract}

Key words: contaminants, environment, health, Inuit, marine mammals, Nunavut, research, risk

RÉSUMÉ. Les Inuits et les scientifiques sont de plus en plus conscients de la présence de contaminants dans le réseau alimentaire de l'Arctique ainsi que des risques que posent ces contaminants à l'égard de la santé et du bien-être de l'être humain et de l'environnement. Les Inuits ont des réactions et des réflexions variées quant à la présence de contaminants dans la nourriture et celles-ci ont fait l'objet d'une étude de cas portant sur la collectivité inuite d'Arviat, sur la côte nord-ouest de la baie d'Hudson. Les réactions vis-à-vis des contaminants sont partagées. Bien que les Inuits soient au courant des constatations scientifiques grâce à divers médias, ils ont également leurs propres explications pour justifier les changements qui se produisent chez les animaux dont ils dépendent. Cette étude juxtapose les causes et les effets à l'échelle planétaire, tels que les scientifiques les comprennent, de même que les causes et les effets de la contamination à l'échelle locale, tels que les Inuits les comprennent. Les Inuits d'Arviat intègrent la recherche sur les contaminants à leur pratique de la chasse et gagnent de l'argent en prélevant des échantillons de tissus et en accueillent les chercheurs du sud. Cette collectivité typique du Nunavut atteste de la compréhension hétérogène qui existe et de la manière dont les gens de la région tirent des avantages d'une situation très négative.

Mots clés : contaminants, environnement, santé, Inuit, mammifère marin, Nunavut, recherche, risque

Traduit pour la revue Arctic par Nicole Giguère.

\section{INTRODUCTION}

Contamination of the Arctic food web is currently a hot topic in social science and ecological research. Recent decades have seen growing concern for the health of Arctic inhabitants because high levels of contaminants are present in the foods they eat (Grondin et al., 1994; Poirier and Brooke, 2000; Downie and Fenge, 2003; Furgal et al., 2005). In 2002, the Department of Indian and Northern Affairs Canada published a five-volume report on contaminants in the Arctic, dealing with the physical and biological environments and human health, and making recommendations on how best to inform Arctic residents of the threats posed by contaminants (NCP, 2002a, b). The Arctic Monitoring and Assessment Programme has been running throughout the circumpolar world since the mid1990s, examining the effects of contaminants on human and animal populations (Reiersen et al., 2003).
This paper is a case study in one Arctic community of the myriad issues surrounding contaminants. It explores the often complex and interwoven thoughts and concerns on the issue, the confusion that sometimes exists, and the multiple understandings of scientists and local people. It examines how Inuit are adapting their dietary habits in response to changes they perceive in the animals they harvest and to advice from scientists and health workers, and incorporating contaminants research into their hunting practice. Perceptions, understandings, and concerns regarding contaminants are complex. Even within a small community, consensus does not exist with regard to the causes of contamination and its effects on animals, or indeed, on humans. This case study of one northern community illuminates the complexities involved and the varied ways Inuit are attempting to deal with this threat to their health and way of life, and to the health of the animals on which they depend.

\footnotetext{
${ }^{1}$ Scott Polar Research Institute, University of Cambridge, Lensfield Road, Cambridge, CB2 1ER, United Kingdom; mt443@ cam.ac.uk (C) The Arctic Institute of North America
} 
The findings discussed here are the result of research conducted for a doctoral thesis on the topic of perception, knowledge, and use of the sea in Arviat, Nunavut (Tyrrell, 2005). In the course of one year, using participant observation as the predominant research method, I set out to explore the relationships that Arviarmiut (residents of Arviat) have with the sea and marine animals, the role the sea plays in the life of their community, and the ways in which they perceive their future as mariners and users of the sea. Throughout the year, I accompanied hunters across the sea ice and open water, learning from them as they harvested seals, whales, and fish. Within the community, I spent a large proportion of my time in the homes of local families, assisting with domestic duties or simply visiting. I also conducted research at the offices of the Arviat Hunters and Trappers Organization, at the local wildlife office, and at the Department of Environment. At each of these, I learned about contaminants from both locals and biologists, each with vested interests in the continued health of the Arctic food web. Through this long-term, indepth field research, I learned the importance of the sea and marine animals to Arviarmiut.

\section{ARVIAT}

Arviat is a community of 2000 people situated on the northwest coast of Hudson Bay, in the Kivalliq region of Nunavut. The sea provides important resources in the form of ringed and bearded seals, beluga whales, polar bears, and arctic char. Seals are hunted year-round, while all other marine species are hunted seasonally as they migrate close to the community. Between 1996 and 2001, the community harvested an average of 455 seals of all species per year (NWMB, 2002). Compared to Inuit in other communities, Arviarmiut eat very little seal meat. Seals are harvested mostly for their pelts and as dog food. Many of those who enjoy a diet that includes seal meat are Inuit who originated in other parts of Nunavut, but now live in Arviat. On average, the community harvests 200 beluga whales each summer and fall for maktaaq - the skin of the whale and fatty layer of blubber underneath (NWMB, 2002) - which is eaten raw or used in a variety of recipes. Polar bear meat is eaten only occasionally by Arviarmiut and, like seals, the 20 bears harvested each year are valued mostly for their pelts. Between 1996 and 2001, the average yearly harvest of arctic char was 3336 fish (NWMB, 2002). These fish, harvested throughout the summer, are enjoyed by most residents.

Although Arviarmiut eat less food from the sea than Inuit in other communities, they still consume enough marine food to give cause for concern regarding contaminants. Kuhnlein et al. (2003:35) have written that, while caribou, ringed seal, and arctic char are the three major Inuit country food items by weight, "the top three contributors of chlordane, PCBs and toxaphene" are narwhal, walrus, and beluga whale blubber. Of these three, beluga whale blubber is widely consumed by Arviarmiut. Local people often discuss at length the changes they have observed in animals and the possible reasons for these changes. These discussions are informed by local knowledge of the marine environment, by the dissemination of scientific findings, and by the conversations Inuit have with scientists who come to the community to conduct contaminant research. Inuit understandings of contaminants are complex. Confusion and concern regarding scientific findings are mirrored by certainties regarding local sources of contamination. At times Inuit and scientists are in agreement about contaminants, while at other times they are poles apart. The responses throughout the community vary, with many people not worrying about the impact of contaminants, while others see them as a major threat to the continued health of individuals within the community.

\section{CONTAMINANTS}

A large number of industrial and naturally occurring substances find their way into the food web by a variety of means. Many of these substances are known to result in neurological and physiological problems in animals and humans. They are also known to increase the incidence of infectious diseases, particularly in children. The origins of these contaminants and their associated health risks are well known (Grondin et al., 1994; Furgal et al., 2005), but I shall briefly summarize some general points and specific findings from Arviat.

\section{Sources of Contamination}

Contaminants can be categorized into three types: (1) persistent organic pollutants (POPs) such as PCBs, DDT, toxaphene, endosulfane, brominated fire retardants, etc.; (2) heavy metals such as mercury and methylmercury, cadmium, and lead; and (3) radionuclides in the form of cesium, polonium and uranium (NCP, 2002a:12). POPs are used as coolants and lubricants, in the making of plastics and insulation fluids, and in marine paint, to prevent unwanted growth of plants or animals on ship hulls. They are also used as pesticides and to prevent human diseases. Heavy metals, found naturally in rocks and soil, are released into the environment from mining and smelting and from the burning of fossil fuels. Mercury can also be released from flooded lands when reservoirs are created. Radionuclides are naturally occurring elements in rocks and soils and can be released into the environment from atmospheric testing of nuclear weapons, dumping of nuclear waste, and nuclear accidents (NCP, 2002a). Some of these contaminants occur in the Arctic, while others find their way there by a variety of means. Heavy metals and other contaminants leach into groundwater and seawater as a result of mining activity in the Arctic and elsewhere and local dumping of domestic and industrial materials. These toxins are transported by 
ocean currents and animals and find their way to locations far from the original source. However, the majority of contaminants found in the Canadian Arctic have neither Canadian nor Arctic sources (NCP, 2002b) but find their way to the circumpolar Arctic from the major industrial areas of Asia, Europe, and the eastern United States (NCP, 2002b). Having been released into the atmosphere, they are carried north primarily on winter winds. Through precipitation, these contaminants find their way onto the land, into rivers and lakes, and into the sea. Contaminants also reach Hudson Bay in the runoff from the southerly rivers and lakes in the Hudson Bay watershed.

Green plants and plankton are at the bottom of the food web in Arctic waters. These are consumed by fish, which in turn are eaten by seals or beluga whales, which are then eaten by polar bears and humans. Younger animals have lower levels of contaminants than older animals, as contaminants build up over time by a process known as bioaccumulation. When an animal eats a plant or another animal, it consumes all the contaminants stored in that food. Higher up the food web, toxin levels increase as contaminants are passed up each level from prey to predator by a process known as biomagnification (NCP, 2002b). Dewailly and Furgal (2003) have noted that Arctic inhabitants are more exposed to contaminants than people at lower latitudes because of their greater reliance on carnivorous animals such as seals and toothed whales that occupy the top levels of the food web.

Within Arviat, tests have been carried out on many migratory and resident species. Arviat's ringed seals have exceptionally high levels of cadmium and PCBs (NCP, 2002b), while beluga whales and polar bears tested in the Arviat area contain extremely high levels of DDT and PCBs (NCP, 2002b). While I have no statistics for arctic char in waters around Arviat, research in Labrador and Nunavik has revealed low to "virtually undetectable" levels of heavy metals, and levels of POPs low enough not to be of concern to humans (NCP, 2002a:51). Other marine animals tested in Arviat, such as ducks, have shown high levels of POPs, heavy metals, and radionuclides. As Arviarmiut consume these important marine species (in particular beluga whales), contaminants make their way into human bodies.

\section{Human Health Risks}

According to research conducted by Kuhnlein and Kinloch (quoted in Dewailly and Furgal, 2003:4), 55\% of Inuit across the Canadian Arctic "consume a daily diet containing heavy metals such as mercury, lead and cadmium. This diet also contains PCBs and chlorinated pesticides, often in quantities exceeding established tolerances." The Northern Contaminants Program (NCP, 2002b) has shown that those most vulnerable to contaminants are women of childbearing age, fetuses, and children. Women pass contaminants on to their children through placental blood and breast milk. Studies in Canada have found that
Inuit mothers "have oxychlordane and trans-nonachlor levels 6-12 times higher than those in Caucasian, Dene and Métis, or Other mothers" (NCP, 2002b:ii), while the breast milk of Inuit mothers in Nunavik has POP concentrations 5-10 times greater than those in the milk of mothers in southern Quebec (Dewailly et al., 1993). More recent research conducted in the United States suggests that in utero exposure to PCBs is more critical to the transmission of contaminants from mothers to children than postnatal exposure through breastfeeding (Dewailly and Furgal, 2003).

Grondin et al. (1994) have listed the principal risks of contaminants to human health, among which are increased risk of cancer, neurological illness, lowered immune system, decreased neural and motor development in children, and renal disease. I shall return to the concept of "risk" below. Grondin et al. (1994) found that in Nunavik neurological illnesses caused by exposure to environmental contaminants were among the principal causes of childhood morbidity and mortality. Other research in Nunavik has found that mothers with elevated levels of PCBs in their blood experienced shorter pregnancies and gave birth to smaller infants (NCP, 2002b). Dewailly and Furgal (2003) report on a Nunavik study that found a correlation between male birth height and exposure to certain POPs. They also report that prenatal exposure to PCBs had a greater impact on birth weight than did the consumption of alcohol and tobacco during pregnancy. These smaller infants may have greater difficulty fighting infections and disease. Studies in the Faroe Islands have shown that high levels of mercury can lead to slower development in children (NCP, 2002b). Longitudinal studies into the effects of prenatal exposure to PCBs and other POPs conducted in the United States, Netherlands, and Germany since the 1980s show effects on "behavioural functioning, slowed growth rates, and negative implications for intellectual functioning up to age eleven" (Dewailly and Furgal, 2003:8). Studies on women in Nunavik and Nuuk link high concentrations of dieldrin to an increased risk of breast cancer, while some anti-estrogen contaminants have been linked to the onset of osteoporosis (Dewailly and Furgal, 2003).

Research into the causes and effects of contaminants is ongoing, but there are still no clear-cut answers. Studies have shown that while one toxin may increase the risk of disease, another may have no effect, and the two combined may have yet other effects (Dewailly and Furgal, 2003). The impact of contaminants on humans and animals is multi-faceted, and other factors such as lifestyle can serve to compound or negate the impact. Alcohol, tobacco, and food additive consumption, for example, can potentially put people at greater risk from contaminants, while the consumption of omega-3 fatty acids and other essential nutrients, combined with the active lifestyle necessitated by the harvesting of country food, can potentially raise an individual's immunity to these contaminating chemicals. New research is being conducted all the time; thus, the 
health advice given to northern residents is constantly under revision.

\section{DISSEMINATING CONTAMINANT INFORMATION AND ADVICE}

The results of scientific research into contamination are disseminated to Inuit communities via radio, $\mathrm{TV}$, newspapers, public posters, and community meetings and workshops for the benefit of various sectors of the community. Inuit are provided with a combination of information on how contaminants move through the food chain, impacts on human health, and practical ways for consumers of country food to reduce their health risks. Scientists are increasingly aware of the potential negative impacts of their findings on local communities. Poirier and Brooke (2000) have written of the social disruption that ensued in Nunavik in the 1980s, when Inuit were told they should no longer eat seal meat because it contained high concentrations of contaminants. The psychological and economic hardships that resulted were compounded by a switch to a diet of store-bought foods that led to other health risks, including heart disease, type-2 diabetes, and tooth decay (Myers and Furgal, 2006). Organizations nowadays are more cautious when issuing warnings against the consumption of certain country foods, advising people to reduce consumption at particular periods of their lives, or to avoid the meat or blubber from certain parts of animals. For example, pregnant women are now advised to consume arctic char because of its important nutritional value (omega-3 fatty acids) and as a means to reduce consumption of other foods that are major sources of contaminants (such as beluga maktaaq) (Dewailly and Furgal, 2003). Mothers are also advised to continue breast-feeding, since breast milk is still considered nutritionally superior to store-bought alternatives despite its high POP levels, and since the highest exposure to contaminants is now believed to be in utero.

In the wildlife office in Arviat, and at the Department of Environment and the Hunters and Trappers Organization offices, visitors are greeted by large, brightly coloured posters that explain how contaminants circulate within the food web. Some of the posters feature maps of the Hudson Bay area, show how contaminants become concentrated as they move up the food web, and offer advice on how to reduce risk. In 2003, the Pauktuutit Inuit Women's Association issued a series of booklets on various aspects of women's health, one of which dealt with pregnant and nursing mothers. These booklets were distributed, free of charge, to every post box in every post office in Nunavut.

On CBC North radio programs, news features from around Nunavut, in both English and Inuktitut, occasionally offer advice on contaminants and other health-related issues. Health workers explain how contaminants get into the human body, how they are passed on from mothers to their children, and how to reduce the risks. In October
2002, I listened to a toxicologist from the World Wildlife Fund (WWF) speaking on CBC North. She encouraged the continued eating of maktaaq, despite concentrations of contaminants. She said people must eat country food for health and cultural reasons and elaborated on ways to reduce risk while eating this food. She stressed the nutritional value of country food, compared to the often nutritionally poor, overprocessed store-bought food that has increasingly become a part of the Arctic diet, but she also explained that there are times when certain country foods should be avoided. As I listened to this radio presentation (in English), I wondered how many local people were taking heed of her advice or even understanding what she was saying (Inuktitut remains the dominant language in Arviat).

In a recent article, Myers and Furgal (2006) explored contaminant awareness among Inuit in four northern communities. Their findings suggest that, despite the high volume of information available in communities and via the media, many northern inhabitants are unaware of the causes of contamination, how contaminants move through the food web, or the potential risks to human health. Of the three sub-groups surveyed (hunters, elders, and women of childbearing age), those least aware of the issue were women of childbearing age. In my research in Arviat, I found contaminant information readily available and visible at public places frequented by hunters, such as the wildlife office and the Hunters and Trappers Organization, but absent from those public places frequented by women and children, such as the schools, health centre, or stores. Myers and Furgal (2006) also write that people expressed a lack of awareness of radio programming devoted to the issue of contaminants. In Arviat, I have found a culture of passive engagement with public media. On occasions when I have attempted to engage Arviarmiut in conversations regarding radio or newspaper stories (to do with hunting quotas, climate change, contaminants, and other issues), my companions have been unaware of the particular stories to which I am referring, despite having their own radios switched on at the time of the broadcast, or having the newspaper in their home. This is not the forum for discussing the social and cultural uses of public media in the Canadian Arctic. However, engagement with the audience is something that must be considered in the dissemination of contaminant advice.

Despite the widespread dissemination of advice regarding contaminants, there appears to be a lack of knowledge or interest in many communities. While language is one reason for this low uptake of information, I believe the greater cause stems from the Inuit worldview and attitude towards risk.

\section{THE PROBLEM WITH “RISK"}

Up to now, the discussion in this paper has focused on the risks associated with contaminants in the food chain. 
Statements such as "increased risk of cancer," "greater susceptibility to," or "infants may have greater difficulty," and so on, pervade the literature. These statements make no direct link between cause and effect simply because often the effects of contaminants are not immediately obvious. There are usually no visible physical changes to a person carrying high levels of contaminants, and it could be years before a person displays any symptoms that might be linked to elevated levels of certain contaminants in the body. The presence of these toxins can lead to greater susceptibility to disease and infection and to the birth of smaller, more vulnerable babies, but no immediate and definite relationships can be made between cause and effect. These contaminants found in the Arctic food web do not often directly lead to people feeling ill or displaying any symptoms, and people therefore find it difficult to make these connections. Problems such as otitis media (middle ear infection), arrested intellectual development in children, and breast cancer, could be secondary effects of elevated contaminant levels, or they might be the result of other factors.

Contaminants are only one determinant of health for circumpolar Arctic inhabitants. Other lifestyle factors affect the health of Inuit of all ages. I have found many Arviarmiut to be heavy smokers. Some consume alcohol and cannabis, and a small number abuse substances such as propane gas. The diet of Inuit must also be taken into consideration. While contaminants in the food web can be detrimental to human health, country food is still viewed by scientists and health-care workers to be nutritionally superior to the often nutritionally poor junk foods that Inuit purchase at the local stores, while the level of physical activity required to harvest country food is also beneficial to health (Kuhnlein et al., 2003). Healthy southern foods are available at the stores in Arviat, but many Arviarmiut, and in particular children, tend to avoid these, and instead over-consume processed, high-fat, low-nutrition junk foods. Even though the majority of Inuit I have spoken to believe country food to be superior, I have shared meals in some Arviat homes where adults consumed country food while their children ate junk food. A reliance on this junk food diet must surely have an adverse effect on health and also contribute to lowered immune systems, poor concentration levels at school, and other effects that could also be attributed to contaminants.

An explanation for parents' tolerance of their children's junk food diet may be found in traditional Inuit practices of naming and rearing children. Inuit children are often named after a recently deceased and loved relative. This "soul-name" confers on the child the relationships of the deceased. For example, a baby girl named after her grandfather becomes, through her name, the husband of her grandmother, the father of her mother, and so on. It would therefore be seen as disrespectful for the mother to chastise her baby daughter, who is also, through her name, the mother's own father. These attitudes toward soul-names and childrearing might best explain the seemingly lacka- daisical attitude of Inuit toward the diet of their children (cf. Briggs, 1972, 1991; Bodenhorn, 2000).

It would seem, therefore, that reaction to the contaminants message is related not only to how the message is disseminated, but also to whether contaminants are perceived as a threat to human or environmental health and how they are weighed against other lifestyle factors. Attitudes to the contaminants message in Arviat are far from uniform. While people are aware of the visible changes occurring in the animals they harvest, the reasons for those changes are not clear and neither are the causes for concern. Contaminants themselves are invisible and cannot be perceived without scientific instruments. Indeed, animals are "contaminated" only because scientists say they are. To the local hunter and consumer of country food, most animals look and taste the same as always, and the threat that comes from food is something imposed by scientific research.

\section{Risk in Modern Society}

Ulrich Beck (1992) describes the modern world as filled with invisible risks, particularly radioactivity, toxins, and pollutants in air, water, and foodstuffs. These substances "induce systematic and often irreversible harm, generally remain invisible, are based on causal interpretations, and thus initially only exist in terms of the (scientific or antiscientific) knowledge about them" (Beck, 1992:23). Douglas (1992), while acknowledging the importance of Beck's work on risk, questions his narrow use of the term. Beck (1992) uses the word "risk" to mean "danger," but he disregards its origins and its current connections with probability theory and the theory of rational choice. Douglas's own use of the concept of "risk" is much more broadbased, as she explores the politicization of risk and its exclusively negative connotations in the modern world. She points out that 'to be 'at risk' is equivalent to being sinned against, being vulnerable to the events caused by others" (Douglas, 1992:45). But can we interpret Inuit attitudes to the risk of contaminants as a reaction to perceived wrongs done against them? Many Inuit are aware of the southern, industrial, origins of contaminants. But Inuit also place some of the blame for contaminants on their own actions within the environment.

The manner in which Inuit perceive risk also has a bearing on how they react to the contaminant issue. As Briggs (1991:259) has pointed out, "Inuit tend to regard the world in all its dimensions as an unstable and dangerously problematic place." Risk, in its original, neutral sense, is a central part of Inuit life. Arviat hunters acknowledge the importance of risk-taking in order to become skillful on land and sea (Tyrrell, 2005). As one Arviat man said, "If you don't take risks you won't learn. You might learn the hard way and die, or you might learn and become knowledgeable. If you are only going to do what is safe, you end up doing nothing" (Tyrrell, 2005:89). Other hunters have spoken similarly of risk as a learning 
tool, but have also acknowledged the risks that have led to fatal accidents on land or sea. Following the deaths of five men in a boating accident in 2000 , one hunter told me, "That could have been me. We all take those risks sometimes."

This culturally specific understanding of risk, combined with a reliance on what is observable and tangible, is reflected in the Inuit attitude towards contaminants. Douglas (1992:51) notes that those who depend on the weather and on understanding tides, such as farmers or fishermen, are used to taking "a huge number of factors into account and [have] rules of thumb for trying to reduce uncertainty." Inuit too have multiple ways of dealing with potential risks, as Briggs (1991:262) points out: "They try to control the uncertainties, they resign themselves, they try not to look too far ahead, and they deinvest [sic], or withdraw emotional involvement, in dangerous situations. Most interestingly, they experiment with uncertainty and with danger." Inuit, therefore, live in a world that they perceive to be full of risk and uncertainty. Yet, rather than shying away from these risks, they incorporate them into their everyday lives, or ignore them, in ways that are meaningful and culturally appropriate.

However, there is another aspect to Inuit reaction to contaminants that cannot be overlooked. Beck (1992:27) writes:

Many of the newer risks (nuclear or chemical contaminants, pollution in foodstuffs, diseases of civilization) completely escape human powers of direct perception. The focus is more and more on hazards which are neither visible nor perceptible to the victims; hazards that in some cases may not even take effect within the lifespans of those affected, but instead during those of their children; hazards in any case that require the 'sensory organs' of science-theories, experiments, measuring instruments - in order to become visible or interpretable as hazards at all.

Contaminants in Inuit food are indeed invisible and imperceptible, they are not explicitly responsible for disease and illness, and the illness occurs long after the food has been consumed. It then comes as no surprise that Arviarmiut have mixed reactions to them. The risks involving contaminants are worth taking, as they allow for continued engagement with the physical environment and appropriate relationships with animals. For Inuit, knowledge is grounded in continual observation and experience (Tyrrell, 2005). Therefore, the scientific culture of indirect perception, through the use of instruments and experimentation, is at odds with the Inuit culture of direct perception and individual lived experience.

These epistemological differences cause much confusion as Inuit come to terms with the changes they observe in the animals they harvest, the information they receive from scientific findings, and the other dietary and health issues they have to deal with. The individual animal one eats may or may not pose a risk, other lifestyle factors increase or decrease the risk, and therefore the Arviarmiut I spoke to feel confused and have mixed feelings regarding contaminants and what to do about them. Life in the Arctic is full of risks, and this is one more to add to the pot.

Scientific findings regarding contamination are often difficult for non-scientists to grasp. The names of pollutants, the means by which they enter the food chain, the levels found in the tissues of various animals, and the effects they have on human health, all create a confusing mélange of information. Douglas (1992) asks how individuals lacking the scientific training to perceive risk can come to accept the warnings and endow them with credibility. From an Inuit perspective, this is not a simple matter. Some Arviarmiut accept, yet ignore, scientific findings, living as they do in a risk-filled environment. The imperceptible risks, as well as the vast global distances over which contaminants travel, are often difficult to comprehend and rationalize, and therefore sometimes easier to ignore.

But not everything is imperceptible and invisible. Inuit have begun to notice changes in the animals they hunt and fish, and these changes have led to concerns about impacts on human health. These visible changes to animals are discussed at length by Arviarmiut. In discussing their worries about human and environmental health, Arviarmiut often combine their own local observations with the more global scientific observations that scientists are presenting to them. It is important, therefore, to explore how Inuit explain contaminants, and how they incorporate their own observations into the information they receive from scientists.

\section{ARVIARMIUT AND CONTAMINANTS}

\section{Recognizing Diseased Animals}

The contaminants discovered by scientists are invisible to the naked eye. Their impact cannot be directly observed. But the diseases and deformities that Inuit have observed in the animals they harvest are tangible phenomena. During my fieldwork, I occasionally heard people talk about deformed animals. Women who sew sealskins often mentioned the poor condition of the skins they were working with. In recent years the skins are sticky all the time, they say, and more difficult to work with. Sticky skins are usually only a feature of seals in rut, but the women say that skins are now like this throughout the year. Some women also say that skins are no longer as shiny as they used to be. The pattern on the skin of arctic char is also said to have changed, and elders wonder if this is a result of changes in the water. The meat on both seals and fish is turning yellow and meat has a different taste these days (this could be a result of a combination of old age and a greater reliance on heavily flavoured processed foods, which leave country food tasting bland by comparison). During summer 2003 brothers Frank and Peter 
Nutarasungnik netted an arctic char with a deformed face. Peter said, "It looked like it crashed into a rock." They and their families ate the other fish netted that day, but worried that while other fish might not have noticeable physical deformities, they too might be diseased in some way, and might cause harm to those who ate them.

The Hudson Bay Ocean Working Group, which aims to develop an integrated management plan for Hudson Bay and its watershed, held one of its twice-yearly meetings in Arviat in February 2002 (Tyrrell, 2005). The effect of runoff from farming and industry into the rivers and lakes and eventually into Hudson Bay was of concern to many of those attending the meeting. Cree, Inuit, and scientists all said they are increasingly finding oddly shaped and coloured mammals and fish. David Alagalak (then mayor of Arviat) spoke of finding seals with little or no fur and one with no skin on the top of its head. Cree women reported finding one-eyed fish in their lakes. They asked the scientists present if these deformed fish were safe to eat.

In 2001, elders were interviewed for the Nunavut Department of Education's Oceans Project. The transcripts of these interviews echo the conversations I had with people within the community, with similar stories of seals and fish that looked odd, or with skin or physical features that were deformed in some way. In May 2005, the Nunavut Wildlife Health Assessment was released (Younger-Lewis, 2005). Thirty hunters from three communities (Arviat, Coral Harbour, and Pangnirtung) interviewed between 2000 and 2002 believe that animal deformities are on the rise, with animals "showing up with deformities like swollen joints and ragged fur." These physical deformities are a real cause for concern to Arviarmiut and people tend to avoid eating those animals exhibiting deformities (cf. Ross et al., 1989). Myers and Furgal (2006:53) report similar findings in other Inuit communities, where people think of "unsafe" food in terms of physical abnormalities (both internal and external).

Inuit are also concerned about other health issues related to animals, such as trichinosis in walrus. Arviarmiut I have spoken to do not make a strict distinction between contaminants and these other health risks related to food consumption. Any illnesses or changes in animals have the potential to affect Inuit hunting practice, Inuit health, and the environment on which Inuit depend. Indeed, there may be a disjuncture between what scientists say and how Inuit rationalize both the information they receive and the changes they observe in the animals they hunt and fish. Contaminants are mostly studied in isolation by scientists, yet for Inuit contaminants cannot be separated from other causes and effects of diseases affecting both humans and animals.

A disjuncture, therefore, exists between the imperceptible contaminants that scientists report and the observable physical changes to animals that Inuit report. From the Inuit perspective, perceptible changes are risks that must be explored and dealt with, while the invisible risks of heavy metals and POPs in the tissues of animals, which have no foundation in experience and observation, can be put to one side. These visible and invisible changes to animals are also reflected in Inuit explanations for the causes of contamination.

\section{Local and Global Causes}

Arviarmiut perceive a number of causes for physical changes in animals. Some of these are informed by the dissemination of scientific findings, but more often than not, Inuit blame themselves for the changes they encounter in the animals they harvest. The statistical findings of Myers and Furgal (2006:52) mirror my findings based on participant observation: "Respondents," they write, "often related the concept [contaminant] to rusted metals, garbage on the land, old batteries, old DEW Line or military sites, or garbage, like seal skins left on the beach." To my knowledge, no scientific research has been conducted into these local factors, which may indeed have an influence on contaminant levels.

When I attended the Hudson Bay Ocean Working Group meeting, David Alagalak spoke of his concern about contaminants in beluga whales. He said, "Belugas are migrating from Churchill out into the open water. There are dams on the rivers and the belugas congregate around river mouths. We don't know what contaminants are in the rivers from the dams. Mercury contaminants have been found in the Great Whale River." Another participant at the meeting pointed out that runoff from farms along the watershed of Hudson Bay is a worrying cause of contamination. Some elders have expressed concern about the increased temperature of seawater around Arviat. They believe that this warmer water has resulted in a lack of food in the sea, and animals, such as seals and whales, now resort to other, less desirable, food sources in order to survive. David Alagalak said, "There are diseases that didn't exist before. They come from eels, clams, cod." He noted that as a result of climate change, the diet of seals and whales has changed dramatically, resulting in physical changes that come from diseases present in these undesirable foods. "Who knows where those diseases have come from?" he asked.

Concerned about the future, David went on to say, "There is talk of building power plants at Chesterfield Inlet or Baker Lake. It will take fifteen years to study the effects of any such development. Yet we are talking about these developments without having the means to study the effects they will have on our animals." With reference to whales and seals, David said, "People from Arviat, Whale Cove and Rankin [Inlet] are eating what comes through Churchill. We are eating the same food as our fathers ate 50 years ago. But you don't know what's going to happen to you in five days, five weeks or five years from now." As these examples show, for Arviarmiut the issue of contaminants cannot be isolated from other issues such as climate change or local industrial development.

While these concerns were related to external sources of contamination, many Arviarmiut, in particular elders, 
blame their own practices for damaging the environment on which they depend. Garbage being dumped in the sea is perhaps the biggest and most commonly cited explanation. During the Oceans Project interviews, elders agreed that animals are sick now because of the amount of garbage left on the ice in winter, which then falls into the sea once the ice melts. One man said, "We used to throw all kinds of garbage into the bay in spring and a lot of the garbage sank to the bottom. We were told not to throw garbage away onto the ice. Older people warned us not to do that because the animals will move away." Another elder pointed out that once break-up occurs, this garbage sinks to the sea floor, drifts out to sea or is washed back up on the coastline. The elders all agreed that the coastline is littered now with the detritus of the modern hunting lifestyle-oil barrels, skidoos, sleds, and boats. One man suggested that the sewage lagoon to the south of Arviat has led to declining numbers of fish and sea mammals in the area. The fluid household waste from the entire community is dumped into the sewage lagoon, from whence it slowly leaches into the sea. People no longer gather mussels or set nets in this area, although they do still fish and hunt for seals at Nuvuq, a point of land northeast of the lagoon.

From this, it is clear that Inuit cite multiple causes for the perceptible changes in animals. They are conscious of the effects of runoff from industrial and agricultural processes farther south, and of the impacts of mining or electricity production, but they are also adamant that they themselves play a role in the changes that are occurring to the animals on which they depend. If scientists are correct, then the impact of global processes is far greater than that of locals dumping small amounts of garbage or their old hunting and traveling equipment in the sea. The local sewage lagoon is but a drop in the ocean compared to the global pollution that is taking place. But these are Inuit concerns and perhaps require more serious investigation by scientists. For Inuit, personal observation and experience are essential to knowledge and understanding (Briggs, 1991), and the tangible explanations proffered by Inuit themselves make more sense than the imperceptible and distant causes of contamination put forward by scientists. By discussing causes in terms of these tangible phenomena, Inuit are attempting to retain control of their knowledge of the environment and of their own actions within that environment.

\section{Human and Environmental Health Concerns}

At the Hudson Bay Ocean Working Group meeting, it was agreed that "health" concerns not just human health but also the health of the environment, which in turn affects human health. David Alagalak said that events happen within communities and people feel they have nowhere to turn for help. If a hunter catches a one-eyed fish or a diseased seal, for example, how is he to have it tested? If he has it sent out to a laboratory, it may be months before results come back. What is he to do in the meantime? He cannot stop hunting or fishing because of one deformed animal. But what if all the animals are contaminated?

One day in summer 2003, I asked William Angalik, a local hunter and schoolteacher, if he was concerned about contaminants. He told me that a few weeks before, he had been down in Churchill when he saw a whale swimming in brown dirty water, and he thought about contaminants then. But usually, he said, he does not give it much thought. He said he thinks about genetically modified food, "mad cow disease" (BSE) and other things and wonders how safe it is to eat beef or chicken from the store. Frank Nutarasungnik, who coordinates the contaminant research program for the Department of Fisheries and Oceans and the WWF (see below), said he does not often think or worry about the contaminant issue. He thinks that country food is still superior to the food at the store. Frank's and William's comments echo those of most Arviarmiut I spoke to on this issue. People recognize the nutritional value of country food, but also value these foods more highly from a cultural perspective (for a detailed ethnography of Inuit food, see Jolles, 2002). Indeed, there has been a drive by scientists and health specialists to encourage the continued consumption of country food and to emphasize not only its nutritional and cultural importance, but also that certain minerals (such as selenium, found in beluga maktaaq) are believed to counteract the impacts of certain contaminants (Dewailly and Furgal, 2003; Kuhnlein et al., 2003).

Some members of the community are more conscious of the potential effects of contaminants on children. During the school year 2000-01, I worked at Levi Angmak Elementary School in Arviat. Many of the children in the school were afflicted with otitis media, an infection of the middle ear, recurrent bouts of which can lead to partial or total deafness. Brenda Mercer, a Grade 5 teacher, believed that otitis media was having a detrimental effect on many of her students, as the deafness and discomfort resulting from recurrent bouts of the infection throughout childhood led to underachievement at school. In her own classroom, she perceived a marked difference in concentration and interest levels between those who suffered from the infection and those who did not (B. Mercer, pers. comm. 2001). Possibly the infected children had greater difficulty hearing what was going on around them and as a result were underachieving or being disruptive. While other causes, such as malnutrition, difficult home circumstances, and so on, may have contributed to the underachievement of these students, it is interesting that their teacher, a longtime resident of Arviat, pointed the finger at contaminants. It would be most instructive if claims such as Mercer's could be scientifically tested.

Thus, reactions to contaminants within the community are mixed. Not everyone is aware that there is a problem, and because the problem is invisible, it is often easy for those who are aware to ignore it. Inuit are also receiving mixed messages from health officials: they are told on the one hand that their country food contains toxins, but on the 
other hand that it is still better to eat than processed, storebought food. Hunters still wish to hunt, and as the consumption of country food is a strong part of family, community, and Inuit identity, people prefer to take their chances with the country food they know and trust.

In their study of Inuit reactions to contaminants in Salluit (Nunavik), Poirier and Brooke (2000) found that the presence of contaminants did not radically modify the way Inuit hunted, prepared, or ate their food. The hunters they spoke to said they were confident they were able to distinguish between what was edible and what was not. This is reflected in Arviat, where Inuit are most concerned by the physical appearance of animals and not by any invisible toxins those animals may carry. Inuit in Salluit were also more concerned about the potential dangers to animals and the subsequent impacts on hunting and eating behaviours than they were about the direct dangers to human health (Poirier and Brooke, 2000). As noted above, because the impacts are mostly invisible, people say they do not think about them too much. But if the presence of contaminants becomes a threat to the animals and to a hunting way of life, then this will be of greater concern.

\section{THE BONUS OF RESEARCH}

There is yet another angle from which to view the contaminants issue in Arviat. Research into contaminants in the food chain is bringing new income opportunities into many northern communities, and Arviat is no exception.

Various marine animal contaminant studies take place in Arviat each year. The World Wildlife Fund employs Frank Nutarasungnik to interview Arviat elders on the changes they have observed in animals over the years. The elders, in turn, are paid for their time being interviewed. Frank also coordinates two sampling projects. He distributes and collects sample kits from hunters and then prepares the samples for shipment to Winnipeg for testing. At different times of year, these samples are taken of beluga whales, seals, and arctic char. Seal sampling takes place in October of each year, and in 2003 hunters earned $\$ 45$ for a completed sample kit. Beluga sampling takes place in August. All these tests are carried out on animals that are primarily harvested for food.

Each kit contains a checklist in English and Inuktitut and plastic bags for 15 different samples. For beluga whales, for example, hunters record the length of the whale, the width of the fluke, sex, age, number of whales in the pod, etc. Samples are taken of maktaaq, liver, lymph nodes, ovaries/testes, and a number of other body parts. Hunters also record additional comments, such as deformities, etc. Hunters receive $\$ 100$ on submission of completed samples and smaller amounts for partially completed kits.

Frank commented that this is a relatively easy way to earn $\$ 100$ and that during one week he had earned $\$ 300$ in half an hour, as this was the length of time it took him to complete the sample kits on the three whales he had harvested. Now that there is a guarantee of $\$ 100$ for a completed kit, he said, it becomes "more fun" than just killing the whales because you know you will get both food and money. Whale and seal hunting now bring not only the reward of food for humans and dogs, but also the potential to earn some much-needed cash for doing a small amount of extra work. While I was out boating with brothers William and Michael Angalik in August 2003, we sighted three beluga whales. As the men prepared to hunt the whales, William said, "If I get a whale that's \$100." On another occasion hunter Eric Qiyuaryok said, "If I get a whale it'll cut my grocery bill in half. I'll get food and money."

The Department of Fisheries and Oceans also actively collects seal samples from hunters. Jawbones are taken to age the animals, the reproductive tracts of females to determine their rate of reproduction, and meat and skin samples to be tested for contaminants, and stomach contents are examined to determine the seal's diet. Hunters are paid various sums of money for providing all of these samples. Scientists are also interested in the movements of seals between hunting areas and how contaminated animals are moving through the food chain in this way. Marine biologists at the Hudson Bay Ocean Working Group meeting said that Inuit traditional knowledge is helping in efforts to locate good places to capture seals in order to tag them for study. They have found (unsurprisingly to most Inuit) that seals tagged in one community have turned up in the boats of hunters from other communities. This is a reflection not only of the distances seals travel, but also of the distances that hunters travel. Hunters are paid for assisting researchers in their endeavours and for sharing their knowledge of seal behaviour.

A small number of Arviarmiut earn money each summer by hosting marine biology students who are conducting contaminant research in the community. Mark and Angie Eetak have been taking in students periodically since the early 1990s. Their first doctoral student is now sending his own graduate students back to the Eetaks each year. The Eetaks provide the students with a bedroom and work space. Angie provides them with meals, and Mark and their son, Ernie, take the researchers out boating to collect whale samples. The first doctoral student all those years ago insisted on taking live samples, so Mark had to capture live whales, hold them steady while the scientist took his samples and then release them. Mark and Angie still laugh at the foolishness and waste of catching a whale and then releasing it again. These days the researchers go boating with Mark and Ernie and take samples from the whales the Eetaks harvest.

In August 2003, at the height of the whaling season, I met one of the students staying with the Eetaks. She was sitting outside the house, surrounded by elaborate freezing equipment and test tubes containing liquids. She told me they had gone out boating at seven o'clock that morning. They had also been out on the previous three days. On the first two days they saw no whales, but on the third there 
were many whales close to shore. The student's interest was in contaminants, and in her portable coolers she had the livers of three whales. She needed to collect ten in total to bring south for testing at her university laboratory. She also had samples of blood and urine to be tested. Angie told me she and Mark were kept busy with the students, preparing food for them and taking them out boating. While they never told me how much they were earning for hosting these students, based on accommodation and research fees in Nunavut, I can imagine they were earning a good sum. Mark and Angie are not the only family to host researchers in this manner. Occasionally rivalry occurs between households as they vie to host researchers. In an economy where cash is often in short supply, the arrival of students for three weeks or a month each summer is a much welcomed source of income.

So while contamination of country food is a worry to some Arviarmiut, it is also opening up opportunities to earn money and contribute to the subsistence economy in novel ways. Hunters are excited at the prospect of earning money while they hunt seals and whales. An extra $\$ 45$ or $\$ 100$ is a bonus to any family and is often reincorporated into hunting practice through the purchase of gas, bullets, or other essential hunting equipment. The contaminants programs also provide year-round part-time employment to people like Frank Nutarasungnik. He can do this job at his own leisure, and it fits easily into his hunting and trapping practices. And for families such as the Eetaks, the arrival of students for a few short weeks every summer is a huge financial bonus, providing families with money to purchase hunting equipment, make home improvements, or even take a vacation.

\section{CONCLUSION}

Scientific and Inuit discourse on the causes and effects of contaminants in the food chain clearly shows two groups of people arriving at the same problem from opposite directions. While scientists make global connections in their understandings of how contaminants are produced, circulate around the world, and accumulate in various species, Inuit attempt to make local connections by reflecting on their own practices that may be adversely affecting the health of the environment they inhabit. David Alagalak and others expressed their desire to have more research conducted on deformed animals. Without proof that there may be local causes for some of these problems, local people will continue to disregard the advice of elders and dump garbage into the sea or along the seashore.

Inuit are concerned not so much about how contaminants affect their health, but rather about the impact on their continued hunting practice. Human health is merely one aspect of concern, interrelated with the health of the environment and cultural health achieved through hunting, sharing, and consumption practices. Unlike the scientists who visit the community for short periods to conduct research, Arviarmiut must continue to hunt and eat animals irrespective of the contamination they may carry. Scientists, however, aware of the impact their advice may have on local communities, make considerable efforts to present their information in culturally sensitive ways.

The contaminant issue in Arviat and across the Arctic is a complex one. Scientists warn that these toxins threaten the health and well-being of Inuit children and adults. The impact that contaminants have on the physical and intellectual development of children is a worry to scientists, who attempt to raise awareness among Inuit without also raising fear and misunderstanding. The threats to life and livelihood posed by contaminants are invisible and therefore at times difficult to understand. And in a culture that places so much emphasis on observation and experience as paths to knowledge, the very imperceptibility of contaminants renders them unknowable to many Inuit. Cultural attitudes to risk also inform how Inuit relate to contaminants; they view them as merely one more form of risk in an already risk-filled environment. For Inuit, risk does not have negative connotations alone. As can be seen from the adoption in Arviat of scientific research as a means to earn income, the risk of contaminants can at times have rewards.

What we can be sure of is that Arviarmiut relationships with the animals they hunt are changing as a result of contaminants. People are no longer sure they can trust the animals they are eating to provide them with health. Animals that appear healthy may, in fact, carry contaminants and diseases that will be passed on to the humans who eat them. Therefore, some Inuit are more wary of what they eat. But relationships with animals are changing in another way too. Through contaminants research, Arviarmiut can earn money from seals, whales, and char in new and innovative ways. These animals no longer represent merely food (and, in the case of seals, pelts): now the diligent hunter can also earn money for a few minutes of extra work.

Participation in contamination research is an example of how Arviarmiut are taking advantage of the new opportunities offered to them by their environment. The presence of contaminants in the food chain could have spelled disaster for Arviat hunters and threatened their way of life and their relationship with the animals they hunted. Instead, these same hunters have embraced the potential of contaminants research, aware that as they earn income from the animals they hunt, they are also contributing to growing knowledge and growing awareness of the contaminants issue. For Arviarmiut, as for other Inuit, the issue of contaminated country food is a double-edged sword. People are aware of the risks inherent in eating contaminated foods, but are also aware that the alternative-overly processed, nutritionally poor, store-bought food-is worse. On the other hand, contaminant research has brought revenue into some Inuit communities (although not necessarily brought greater awareness to those most at risk), allowing those who avail themselves of the opportunities to earn money in novel ways. Therefore 
while contaminants pose risks, they also allow for increased access to cash, and thus the opportunity to hunt more often.

Like all places in the North, Arviat is in many ways unique, but in many other ways similar to other communities. This paper has attempted to offer a glimpse into the varied reactions to contaminants in this one community. There are no simple answers to this issue, but by examining in greater detail the many questions that local people have and their many responses to the toxins in their food and their environment, we can move a step closer to understanding the needs and concerns of local Arctic peoples.

\section{ACKNOWLEDGEMENTS}

I wish to thank Arnar Arnasson and Peter Bates, Department of Anthropology, University of Aberdeen, for their helpful comments on an earlier draft of this paper. The paper also benefited from the comments of two anonymous reviewers.

\section{REFERENCES}

BECK, U. 1992. Risk society: Towards a new modernity. London: Sage Publications.

BODENHORN, B. 2000. 'He used to be my relative': Exploring the bases of relatedness among Inupiat of northern Alaska. In: Carsten, J., ed. Cultures of relatedness: New approaches to the study of kinship. Cambridge, United Kingdom: Cambridge University Press. 128-148.

BRIGGS, J. 1972. Never in anger: Portrait of an Eskimo family. Cambridge, Massachusetts: Harvard University Press.

1991. Expecting the unexpected: Canadian Inuit training for an experimental lifestyle. Ethos 19(3):259-287.

DEWAILLY, E., and FURGAL, C. 2003. POPs, the environment and public health. In: Downie, D.L., and Fenge, T., eds. Northern lights against POPs: Combatting toxic threats in the Arctic. Montreal: McGill-Queen's University Press. 3-21.

DEWAILLY,E., BRUNEAU, S., LALIBERTÉ, C., and GINGRAS, S. 1993. La contamination du lait maternel au Nunavik: évaluation des risques pour la santé des nourrissons. Sainte-Foy: Service Santé et Environnement, Centre de santé publique de Québec.

DOUGLAS, M. 1992. Risk and blame: Essays in cultural theory. London: Routledge.
DOWNIE, D.L., and FENGE, T., eds. 2003. Northern lights against POPs: Combatting toxic threats in the Arctic. Montreal: McGillQueen's University Press.

FURGAL, C.M., POWELL, S., and MYERS, H. 2005. Digesting the message about contaminants and country foods in the Canadian North: A review and recommendations for future research and action. Arctic 58(2):80-87.

GRONDIN, J., PROULZ, J.-F., BRUNEAU, S., and DEWAILLY, E. 1994. Santé publique et environnement au Nunavik. Études/ Inuit/Studies 18(1-2):225-251.

JOLLES, C.Z. 2002. Faith, food and family in a Yup'ik whaling community. Washington: University of Washington Press.

KUHNLEIN, H., CHAN, L.H.M., EGELAND, G., and RECEVEUR, O. 2003. Canadian Arctic indigenous peoples, traditional food systems, and POPs. In: Downie, D.L., and Fenge, T., eds. Northern lights against POPs: Combatting toxic threats in the Arctic. Montreal: McGill-Queen's University Press. 22-40.

MYERS, H., and FURGAL, C. 2006. Long-range transport of information: Are arctic residents getting the message about contaminants? Arctic 59(1):47-60.

NCP (NORTHERN CONTAMINANTS PROGRAM). 2002a. Canadian Arctic contaminants assessment report II: Highlights. Ottawa: Ministry of Indian and Northern Affairs.

- 2002b. Canadian Arctic contaminants assessment report II: Human health. Ottawa: Ministry of Indian and Northern Affairs.

NWMB (NUNAVUT WILDLIFE MANAGEMENT BOARD). 2002. The Nunavut Wildlife Harvest Study: Five-year preliminary report for Arviat. Iqaluit: NWMB.

POIRIER, S., and BROOKE, L. 2000. Inuit perceptions of contaminants and environmental knowledge in Salluit, Nunavik. Arctic Anthropology 37(2):78-91.

REIERSEN, L.-O., WILSON, S., and KIMSTACH, V. 2003. Circumpolar perspectives on persistent organic pollutants: The Arctic Monitoring and Assessment Programme. In: Downie, D.L., and Fenge, T., eds. Northern lights against POPs: Combatting toxic threats in the Arctic. Montreal: McGill-Queen's University Press. 60-86.

ROSS, P., OLPINSKI, S., and CURTIS, M. 1989. Relationships between dietary practice and parasite zoonoses in northern Quebec Inuit communities. Études/Inuit/Studies 13(2):33-47.

TYRRELL, M. 2005. Perception, knowledge and use of the sea in Arviat, Nunavut. PhD thesis, University of Aberdeen, Scotland. YOUNGER-LEWIS, G. 2005. Animal deformities on the rise, hunters say. Nunatsiaq News, May 20. 